
\title{
RADIOGRAPHIC FEATURES AND TREATMENT STRATEGIES OF
IMPACTED MAXILLARY CANINES
}

\begin{abstract}
Objective: Treatment of impacted maxillary canines is essential, both aesthetically and functionally. This study aims to define the radiographic features of maxillary impacted canines, evaluate treatment options, and to detect related pathologies.
\end{abstract}

Materials and Methods: In this retrospective study, orthopantomographs, treatment options, and demographic features of the patients were analyzed. Impacted maxillary canines were classified according to the study of Yamamoto et al. According to this classification, maxillary canines are evaluated under seven types according to the occlusal plane and their relative location to adjacent teeth. Moreover, the pathologies around impacted canines were detected via panoramic radiographies.

Results: 323 impacted maxillary canines of 270 patients were analyzed. Two hundred fifteen of these teeth $(66.6 \%)$ belonged to females, while the rest 108 (33.4\%) belonged to males. It was observed that impacted maxillary canines were bilateral in 53 patients and unilateral in 217 patients. In the classification based on direction and position of impacted maxillary canines, the highest rates was Type $2(55.42 \%)$ which was followed by Type 4 (26.93\%), Type 1 (12.38\%), Type 7 (2.79\%), Type 3 (1.86\%) and Type 5 $(0.62 \%)$, respectively. Twenty-eight patients with cystic lesion related to impacted maxillary canines were detected. Impacted maxillary canines concomitant with odontoma was detected in 4 patients. In 52 of the patients, it was detected that maxilla was edentulous except for the impacted canines, and the extractions of impacted canine teeth were due to prosthetic reasons. Thirty impacted maxillary canines of 24 patients $(n=30,9.28 \%)$ were placed buttons for orthodontic maintenance, while surgical tooth extraction was preferred as a treatment option in other patients.

Conclusions: Orthodontic, surgical treatments or combinations may be preferred depending on the impact level of the canine. Early diagnosis and correct orientation of the patient is essential for the success of the treatment.

\author{
*Ahmet ALTAN ${ }^{1}$ \\ iD Sefa ÇOLAK ${ }^{1}$ \\ (D) Nihat AKBULUT ${ }^{1}$ \\ (D) Halenur ALTAN ${ }^{2}$
}

ORCID IDs of the authors:

A.A. $0000-0003-2041-6364$

S.C.. $0000-0002-0807-9089$

N.A. $0000-0001-6950-8214$

H.A. $0000-0003-3648-5989$

\footnotetext{
${ }^{1}$ Tokat Gaziosmanpasa University Faculty of Dentistry, Department of Oral and Maxillofacial Surgery, Tokat, Turkey.

${ }^{2}$ Tokat Gaziosmanpasa University Faculty of Dentistry, Department of Pediatric Dentistry, Tokat, Turkey.
}

Keywords: Impacted, maxilla, tooth, tooth extraction.

How to Cite: Altan A, Çolak S, Akbulut N, Altan H.Radiographic Features and Treatment Strategies of Impacted Maxillary Canines. Cumhuriyet Dent J 2020;23:1;32-37. 


\section{INTRODUCTION}

Description of impacted teeth comprises teeth that could not take its place on dental arch and impacted partially or wholly in bone or soft tissue. ${ }^{1}$ Despite the differences observed among people, third molar teeth are the most impacted teeth in general, and they are followed by canine teeth. $^{2-4}$ The impact incidence of maxillary canines varies between $0.8 \%$ and $3.6 \% .^{5}$ Impact incidence of mandibular canines is more rare than maxillary canines and it was reported that this incidence is 20 times lower than of maxillary canines. $^{6}$

Despite some cases where an impacted tooth migrates from its development area to another distance, the tooth stays on the same side of the middle line in general. The rare phenomena in which the tooth passes the middle line is called as "tooth transmigration". Although various terminologies have been used to define this case, the "transmigration" term is widely used to define this phenomenon. Transmigration is more widely observed in mandibular canines than in maxillary canines. ${ }^{7}$ Specific etiology of this anomaly has not been known yet; however, causal factors may be traumatic factors, genetic factors, long eruption line of canines, the early loss of deciduous teeth, incompatibility between tooth sizes, inadequate length of dental arch and odontomas., ${ }^{8,9}$

Treatment of impacted teeth is essential, both aesthetically and functionally. ${ }^{10}$ Among the treatment options for impacted canines, surgical, and orthodontic treatment options may be evaluated separately or as a combination. In the surgical option, the spontaneous eruption of the tooth may be planned by opening the eruption line. Spontaneus eruption of the tooth may be provided by removing the odontoma or similar pathologies lying on the eruption line. The impacted tooth may be drawn to the dental arch by placing a button on the crown of an impacted tooth and applying orthodontic force. In cases where orthodontic treatment cannot be applied, tooth extraction is evaluated as a general treatment option. ${ }^{11}$ In cases where the impacted canines cannot be treated, some phenomena as transmigration between adjacent teeth, loss of vitality in adjacent teeth, contraction in dental arch, cystic pathologies based on dental follicles, ankylosis, internal and external resorption, recurrent infections, pain and combination of these may be observed. ${ }^{12,13}$

This study aims to define the radiographic features of maxillary impacted canines, evaluate treatment options, and detecting related pathologies.

\section{MATERIAL AND METHODS}

Ethical committee approval was obtained from Ethical Committee of Clinical Researches of Tokat Gaziosmanpaşa University (Project no: 18KAEK-285). In this retrospective study, orthopantomographs, treatment options, and demographic features of the 270 patients who had admitted to the Department of Oral and Maxillofacial Surgery, Faculty of Dentistry in Tokat Gaziosmanpaşa University due to impacted maxillary canine between March 2013 and January 2019 were analyzed. The study includes the patients above 13 years of age who had no developmental or systemic diseases and whose impacted maxillary canine was placed an extraction indication or who underwent a button application for orthodontic treatment after clinical and radiologic treatment in Department of Oral and Maxillofacial Surgery. The patients who have a genetic disorder causing developmental and eruption problems in the development and eruption of teeth and whose demographic features could not be accessed were excluded from the study. Impacted maxillary canines were classified according to the study of Yamamoto et al. ${ }^{14}$ According to this classification, maxillary canines are evaluated under seven types according to the occlusal plane and their relative location to adjacent teeth (Figure 1).

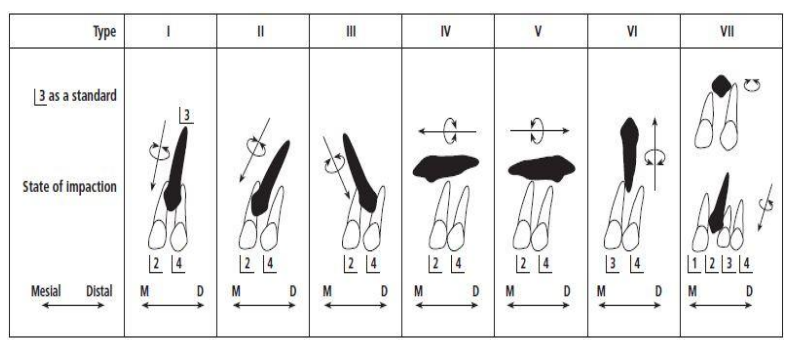

Figure 1. According to Yamamoto et al. ${ }^{14}$ classification of impacted maxillary canines 
Moreover, the pathologies around impacted canines were detected via panoramic radiographies.

SPSS 19 (IBM SPSS Statistics 19, SPSS inc., an IBM Co., Somers, NY) program was used in the statistical analysis of study data Variables were recorded and analyzed by descriptive statistics.

\section{RESULTS}

In this study, 323 impacted maxillary canines of 270 patients (173 females and 97 males) were analyzed. Two hundred fifteen of these teeth $(66.6 \%)$ belonged to females, while the rest 108
(33.4\%) belonged to males. The age of the patients varied between 13-77 (average: $38.74 \pm$ 18.12). It was observed that impacted maxillary canines were bilateral in 53 patients (42 female, 11 male) and unilateral in 217 patients. In the classification based on direction and position of impacted maxillary canines, the highest rates was Type $2(55.42 \%)$ which was followed by Type 4 (26.93\%), Type $1(12.38 \%)$, Type 7 (2.79\%), Type $3(1.86 \%)$ and Type $5(0.62 \%)$ respectively. There were no cases classified in Type 6 . Impacted maxillary canines were mostly localized at left side ( $\mathrm{n}=171, \%$ 52.94) (Table-1).

Table1.Distribution of impacted maxillary canines by gender and the type of impaction.

\begin{tabular}{lcccccc}
\hline Type & \multicolumn{2}{c}{ Localization } & \multicolumn{2}{c}{ Gender } & \multicolumn{2}{c}{ Total } \\
& Right $(\# \mathbf{1 3})$ & Left $\mathbf{\# 2 3 )}$ & Female & Male & n & \% \\
\hline Type 1 & 25 & 15 & 28 & 12 & 40 & 12.38 \\
Type 2 & 83 & 96 & 118 & 61 & 179 & 55.42 \\
Type 3 & 4 & 2 & 5 & 1 & 6 & 1.86 \\
Type 4 & 36 & 51 & 56 & 31 & 87 & 26.93 \\
Type 5 & 0 & 2 & 2 & 0 & 2 & 0.62 \\
Type 6 & 0 & 0 & 0 & 0 & 0 & 0 \\
Type 7 & 4 & 5 & 6 & 3 & 9 & 2.79 \\
Total & 152 & 171 & 215 & 108 & 323 & 100 \\
\hline
\end{tabular}

The age distribution of patients showed that a significant number of patients with impacted maxillary canines are between 13-20 of ages (Table-2).

Table 2. Age distribution of patients with impacted maxillary canines.

\section{Number of impacted teeth}

\begin{tabular}{ccc} 
Age (years) & $\mathbf{n}$ & $\%$ \\
\hline $13-20$ & 94 & 29.1 \\
$21-30$ & 45 & 13.93 \\
$31-40$ & 33 & 10.22 \\
$41-50$ & 45 & 13.93 \\
$51-60$ & 63 & 19.51 \\
$>60$ & 43 & 13.31 \\
Total & 323 & 100 \\
\hline
\end{tabular}

Twenty-eight patients (10.4\%) with cystic lesion related to impacted maxillary canines were detected (Figure-2). Impacted maxillary canines concomitant with odontoma was detected in 4 patients (1.5\%) (Figure-3). In 52 of the patients (19.3\%), it was detected that maxilla was edentulous except for the impacted canines, and the extractions of impacted canine teeth were due to prosthetic reasons. Thirty impacted maxillary canines of 24 patients $(n=30$, 9.28\%) were placed buttons for orthodontic 
maintenance, while surgical tooth extraction was preferred as a treatment option in other patients.

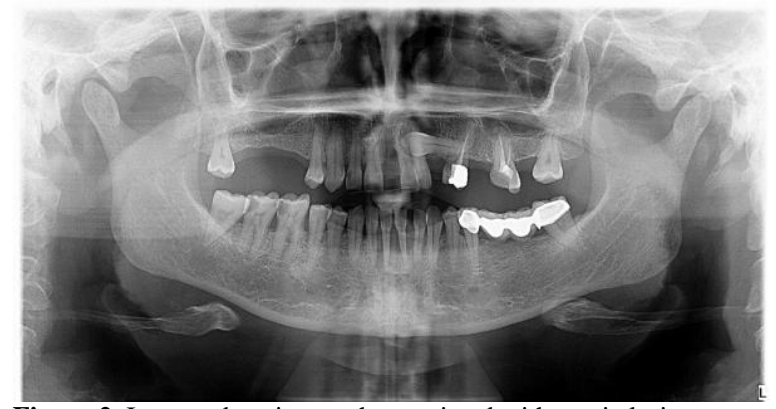

Figure 2. Impacted canine tooth associated with cystic lesion

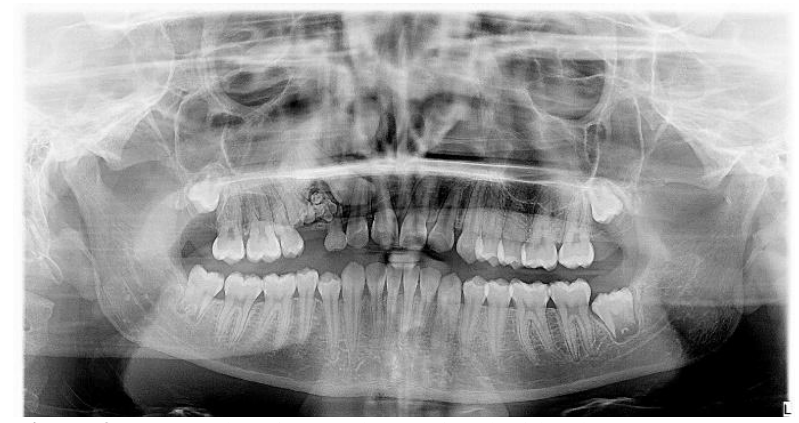

Figure 3. Impacted canine tooth associated with odontoma

\section{DISCUSSION}

Maxillary canines play an important role in both aesthetically and functionally. Although the bilateral impact of maxillary canine is a frequent phenomenon, unilateral ectopic eruptions are more frequent. ${ }^{14,15}$ In this study, the unilateral impact was more frequently observed. When the localization of impacted maxillary canines are analyzed, it is observed that the impacted maxillary canines are frequently located on the left side. ${ }^{1,16}$ Despite the lack of any scientific evidence to show the high prevalence of left-sided impacted maxillary canines, it has been accepted as a general malformation. In this study, too, the left-sided impacted maxillary canine was more frequently observed.

Yamamoto et al. ${ }^{14}$ were reported that impacted canines were more frequently observed in females. Similarly, in this study, 215 of 270 impacted canines were observed in females. Despite the lack of any literature about jawbone sizes of people with an impacted tooth, we believe that gender differences as the fact that females have smaller cranium, maxilla, and mandible than of males, may have an effect on this situation. Al-Zoubiet $a l^{l}$ reported that Type 2 was more frequent among other types of impacted maxillary canines. However, in the study of Yamamoto et $a l .{ }^{14}$, Type 1 of impact is more frequent. In this study, Type 2 was the most frequently observed type of impact.

Patients are generally not aware of their impacted canines. They do not consult dentists unless they have problems like pain or swelling. The impacted tooth or persistent deciduous tooth is generally explored during the examination and confirmed via radiographies. Clinical examination includes inspection and palpation. ${ }^{17}$ From the age of 8 years, the alveolar process on the distal side of the lateral incisor can palpate the buccal surface and open the position of the maxillary canine teeth, and this was offered as a diagnostic tool by Kettle. ${ }^{18}$ Radiographic evaluation of jaws is an important diagnostic tool in the diagnosis and localization of impacted teeth. A radiograph is required for 3D (vertical, mesiodistal, and buccopalatal) imaging of the impacted canines, observing the relations with the middle line and neighboring teeth, and evaluating any resorption. ${ }^{19}$ In the evaluation of impacted canine; Panoramic, periapical, cephalometric, lateral skull and maxillary occlusal, CT, and CBCT are widely used. ${ }^{17} \mathrm{CBCT}$ is the most sensitive radiographic localization method, which maximizes diagnostic efficiency and reduces radiation exposure. Total radiation is about $20 \%$ of conventional CTs. ${ }^{20,21}$ CBCT eliminates problems such as magnification and superimposition in conventional radiographs. In orthodontics and pedodontics, underestimating the degree of resorption in maxillary canine is a common problem. CBCT increases resorption detection by $50 \% .^{22}$ For these reasons, the use of three-dimensional imaging methods for the maxillofacial region has become more common than traditional radiographs. ${ }^{23}$

The demands of the patient should also be taken into account while deciding on treatment. Long-term follow of a tooth, extraction of the tooth, re-drawn of the tooth to its position on the dental arch by orthodontic movement, autotransplantation of the tooth, simultaneous dental implant placement after the extraction of the impacted tooth may be evaluated as treatment options for impacted canines. ${ }^{24,25}$ Cyst formation 
between possible sequels of impacted canines, internal resorption of an impacted tooth, external resorption of impacted or adjacent teeth, ankylosis, infection, and migration of neighboring teeth may also be included. ${ }^{26}$ For this study, the surgical extraction reasons for impacted teeth may be evaluated as pathological formations as cyst and tumor-related to the impacted tooth, malposition of especially lateral teeth, and prosthetic reasons in edentulous patients.

Besides traditional surgical applications, Bensaha et $a .^{27}$ also suppose ultrasonic surgery for the treatment of impacted canines. The main advantages of ultrasonic surgery are facing no bleeding or no tissue necrosis and the chance of placing the brackets during the same visit. Baccetti et al. ${ }^{28}$ suggest transpalatal arch therapy to be used as a treatment for impacted maxillary canine teeth. This option helps to control the movement of maxillary first molar teeth. Thus, the location of permanent maxillary canines is preserved, and spontaneous eruption can be induced. Moreover, mini-screws can be used when extrusion of impacted maxillary canine teeth is needed. Roth et al. ${ }^{29}$ successfully performed a case where the maxillary canine was extruded via a mini-screw.

\section{CONCLUSIONS}

Impacted maxillary canine teeth are usually diagnosed using panoramic imaging or cone-beam computed tomography. Cone-beam computed tomography is one of the most accurate diagnostic methods to identify the localization of affected maxillary canines. Orthodontic, surgical treatments or combinations may be preferred depending on the impact level of the canine. Early diagnosis and correct orientation of the patient is important for the success of the treatment.

\section{Gömülü Maksillar Kanin Dişlerin Radyografik Özellikleri ve Tedavi Stratejileri}

\section{$\ddot{O} Z$}

Amaç: Gömülü kanin dişlerinin tedavisi estetik ve fonksiyon açısından önem taşımaktadır. Bu çalışmanın amacl; maksillar gömülü kanin dişlerin, radyografik özelliklerini belirlemek, tedavi seçeneklerini değerlendirmek ve ilgili patolojileri tespit etmektir. Gereç ve Yöntem: Bu retrospektif çalışmada, hastaların ortopantomograf radyografileri, tedavi seçenekleri ve demografik özellikleri analiz edildi. Gömülü maksillar kaninler; Yamamoto ve arkadaşları tarafindan yapılan sinuflamaya göre gruplara ayrıldl. Bu siniflamaya göre maksillar kaninler oklüzal düzleme ve komşu dişlere konumlarına göre 7 tipe ayrllmıştır. Ayrıca; panaromik radyografilerden gömülü kanin dişler etrafindaki patolojiler tespit edildi. Bulgular: Çalış̧mada, 270 hastaya (173 kadın, 97 erkek) ait 323 gömülü maksillar kanin diş analiz edildi. Bu dişlerin $215^{\prime} \mathrm{i}(\% 66,6)$ kadınlarda, 108'si (\%33,4) erkeklerde görüldü. Maksillar gömülü kanin dişler 53 hastada (42 kadın, 11 erkek) bilateral, 217 hastada unilateral olarak tespit edildi. Maksillar kaninlerin yönü ve pozisyonuna göre yapılan sinuflamada en yüksek oran Tip 2 $(\% 55,42)$ 'de onu takiben sirastyla, Tip $4(\% 26,93)$, Tip 1 (\%12,38), Tip 7 (\%2,79), Tip 3 (\%1,86), Tip 5 $(\% 0,62)$ idi. 28 hastada gömülü maksillar kanin dişlerle ilişkili kistik lezyon tespit edildi. 4 hastada ise gömülü maksillar kanin dişe odontoma eşlik ediyordu. Hastaların 52'sinde gömülü kanin dişler haricinde maksillanin total dişsiz olduğu ve protetik amaçlarla çekim gerçekleş̧tirildiği belirlendi. 24 hastada 30 gömülü maksillar kanin dişe ortodontik olarak sürdürülme amacryla buton yerleştirildi, diğer hastalarda ise tercih edilen tedavi yöntemi cerrahi çekimdi. Sonuçlar: Kanin dişin gömülülük derecesine bağll olarak; tedavide ortodontik, cerrahi ya da kombinasyonlarl tercih edilebilir. Tedavinin başarısında erken tanı ve hastanın doğru yönlendirilmesi önemlidir. Anahtar Kelimeler: Gömülü, maksilla, diş, diş çekimi.

\section{REFERENCES}

1. Al-Zoubi H, Alharbi AA, Ferguson DJ, Zafar MS. Frequency of impacted teeth and categorization of impacted canines: A retrospective radiographic study using orthopantomograms. Eur J Dent 2017;11:117121.

2. Pedro FL, Bandeca MC, Volpato LE, Marques AT, Borba AM, Musis CR, et al. Prevalence of impacted teeth in a Brazilian subpopulation. J Contemp Dent Pract 2014;15:209-213.

3. Damlar İ, Altan A, Tatlı U, Arpağ OF. Retrospective Investigation of the Prevalence of Impacted Teeth in Hatay. Cukurova Medical Journal 2014;39:559-565.

4. Uğur Aydın Z, Korkmaz YN, Sarıoglu B. Radiographic Investigation of The Relationship 
Between Dental Malocclusions And Dental Anomalies on the Turkish Population. Cumhuriyet DentJ 2018;21:343-349.

5. Aydin U, Yilmaz HH, Yildirim D. Incidence of canine impaction and transmigration in a patient population. Dentomaxillofac Radiol 2004;33:164-169.

6. Bhullar MK, Aggarwal I, Verma R, Uppal AS. Mandibular Canine Transmigration: Report of Three Cases and Literature Review. J Int Soc Prev Community Dent 2017;7:8-14.

7. Joshi MR. Transmigrant mandibular canines: a record of 28 cases and a retrospective review of the literature. Angle Orthod 2001;71:12-22.

8. Sumer P, Sumer M, Ozden B, Otan F. Transmigration of mandibular canines: a report of six cases and a review of the literature. J Contemp Dent Pract 2007;8:104-110.

9. Celikoglu M, Kamak H, Oktay H. Investigation of transmigrated and impacted maxillary and mandibular canine teeth in an orthodontic patient population. J Oral Maxillofac Surg 2010;68:1001-1006.

10. Alhammadi MS, Asiri HA, Almashraqi AA. Incidence, severity and orthodontic treatment difficulty index of impacted canines in Saudi population. J Clin Exp Dent 2018;10:e327-e334.

11. Becker A, Chaushu S. Surgical Treatment of Impacted Canines: What the Orthodontist Would Like the Surgeon to Know. Oral MaxillofacSurg Clin North Am 2015;27:449-458.

12. Bonardi JP, Gomes-Ferreira PH, de Freitas Silva L, Momesso GA, de Oliveira D, Ferreira S, et al. Large Dentigerous Cyst Associated to Maxillary Canine. J CraniofacSurg 2017;28:e96-e97.

13. Guarnieri R, Cavallini C, Vernucci R, Vichi M, Leonardi R, Barbato E. Impacted maxillary canines and root resorption of adjacent teeth: A retrospective observational study. Med OralPatol Oral Cir Bucal 2016;21:e743-e750.

14. Yamamoto G, Ohta Y, Tsuda Y, Tanaka A, Nishikawa $M$, Inoda $H$. A new classification of impacted canines and second premolars using orthopantomography. Asian Journal of Oral and Maxillofacial Surgery 2003;15:31-37.

15. Thilander B, Myrberg N. The prevalence of malocclusion in Swedish schoolchildren. Scand J Dent Res 1973;81:12-21.

16. Takahama Y, Aiyama Y. Maxillary canine impaction as a possible microform of cleft lip and palate. Eur J Orthod 1982;4:275-277.

17. Counihan K, Al-Awadhi EA, Butler J. Guidelines for the assessment of the impacted maxillary canine. Dent Update 2013;40:770-777.

18. Kettle MA. Treatment of the unerupted maxillary canine. Trans Br Soc Orthod 1957:74-78.

19. Stivaros N, Mandall NA. Radiographic factors affecting the management of impacted upper permanent canines. J Orthod 2000;27:169-173.

20. Preda L, La Fianza A, Di Maggio EM, Dore R, Schifino MR, Campani R, et al. The use of spiral computed tomography in the localization of impacted maxillary canines. Dentomaxillofac Radiol 1997; 26:236-241.

21. Mah JK, Danforth RA, Bumann A, Hatcher D. Radiation absorbed in maxillofacial imaging with a new dental computed tomography device. Oral Surg Oral Med Oral Pathol Oral Radiol Endod 2003;96:508513.

22. Ericson S, Kurol PJ. Resorption of incisors after ectopic eruption of maxillary canines: a CT study. Angle Orthod 2000;70:415-423.

23. Bayrak S, Sezgin OS, Kayıpmaz, Çan G. The Effect of Slice Thickness on the Volume Estimations Performed by Using Cone Beam CT. Cumhuriyet Dent J 2018;21:167-172.

24. Sajnani AK, King NM. Retrospective audit of management techniques for treating impacted maxillary canines in children and adolescents over a 27-year period. J Oral Maxillofac Surg 2011;69:2494-2499.

25. Penarrocha M, Penarrocha M, Garcia-Mira B, Larrazabal C. Extraction of impacted maxillary canines with simultaneous implant placement. J Oral Maxillofac Surg 2007;65:2336-2339.

26. Bishara SE. Impacted maxillary canines: a review. Am J Orthod Dentofacial Orthop1992;101:159-171.

27. Bensaha T. A new approach for the surgical exposure of impacted canines by ultrasonic surgery through soft tissue. Int $\mathbf{J}$ Oral Maxillofac Surg 2013;42:1557-1561.

28. Baccetti T, Sigler LM, McNamara JA, Jr. An RCT on treatment of palatally displaced canines with RME and/or a transpalatal arch. Eur J Orthod 2011;33:601-607.

29. Roth A, Yildirim M, Diedrich P. Forced eruption with microscrew anchorage for preprosthetic leveling of the gingival margin. Case report. J Orofac Orthop 2004;65:513-519. 